\title{
THE WADA TEST WITH PROPOFOL IN A PATIENT WITH EPILEPSY
}

\author{
TICYANA M. SILVA*, OTTO J. HERNÁNDEZ-FUSTES ${ }^{* *}$, MARISTELA L. BUENO***,

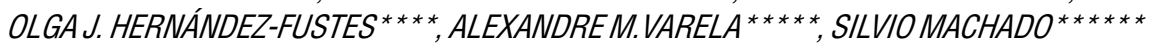

\begin{abstract}
The usual drug used in the Wada test is amobarbital, but it is not available in Brazil. Propofol was already used by Bazin et al. in 1998, and in their report the test resulted good in the absence of any adverse effect. We report the use of propofol as the anesthetic for the Wada test. The test was carried out in a 26 years old woman with temporal medial lobe epilepsy refractory to medical treatment. Language functions and memory were tested after injection in both hemispheres by three procedures (Seattle, Montreal and Interview procedures). Propofol showed to be good to carry on the Wada test.
\end{abstract}

KEY WORDS: Wada test, epilepsy, propofol, temporal lobe epilepsy.

\section{Teste de Wada com propofol em uma paciente com epilepsia}

RESUMO - O amobarbital é a droga usada no teste de Wada, mas não é disponível em nosso pais. O propofol, usado por Bazin et al. em 1998, foi útil e sem efeitos adversos. Relatamos o uso do propofol como anestésico no teste de Wada. Este foi realizado como parte da avaliação pre-cirúrgica, em uma mulher de 26 anos com epilepsia do lobo temporal mesial, em uso de carbamazepina e ácido valpróico sem controle de suas crises. As funções da linguagem e memória foram testadas após injeção em ambos hemisférios separadamente por três procedimentos (Seattle, Montreal e Entrevista). O propofol mostrou-se eficaz para a realização do teste de Wada.

PALAVRAS-CHAVE: teste de Wada, epilepsia, propofol, epilepsia do lobo temporal.

The determination of hemispheric lateralization of language functions in patients who may have epilepsy surgery can be made by the Wada test ${ }^{1}$. Coming after, the test was expanded to evaluate the risk of developing an amnesic disorder after surgery intervention ${ }^{2,3}$.

This test involves unilateral injection of a short-acting barbiturate into an internal carotid artery ${ }^{4}$. The usual barbituric used in this test is amobarbital diluted in saline solution. However, amobarbital is not available in Brazil, so it was decided to introduce propofol to carry out the Wada test. Propofol is an anesthetic that acts at central nervous system. Its chemical structure is 2,6 diisopropil fenol ${ }^{5}$, it is insoluble in water and is delivered alike an oil solution $(10 \mathrm{mg} / 1 \mathrm{ml}$ of solution).

Propofol was chosen to substitute sodium amobarbital after inadvertent intraarterial administration did not result in local constriction or damage to vessel structure ${ }^{6}$. Propofol was already used to achieve a Wada test as described by Bazin et al. and in their study the test resulted in absence of any adverse effect ${ }^{7}$.

Epilepsy Center, Neurology Department of the Cajuru University Hospital at Pontifical Catholic University, Paraná, Brazil: *Neuropsychologist; **MD, MSc, Neurologist; ***MD, Neuroanesthesist; ****MD, Neurophysiologist; ***** MD, MSc, Hemodinamicist; ******MD, Neurosurgeon. Aceite: 7-janeiro-1999.

Dr. Otto J. H. Fustes - Av. São José 300 - 80050-350 Curitiba PR - Brasil. E-mail: neurohuc@ rla13.pucpr.br 


\section{CASE REPORT}

A 26 years old consenting woman, presenting partial simple psychical and sensorial seizures weekly in treatment with carbamazepine $(1200 \mathrm{mg} / \mathrm{d})$ and sodium valproate $(1500 \mathrm{mg} / \mathrm{d})$, previously underwent an investigation at the Epilepsy Center of Hospital Universitário Cajuru, Curitiba, Paraná, Brazil, with medical, neurological and neuropsychological evaluation. The video EEG revealed intercritic bilateral and left occipital epileptiform activity, with left temporal dominance and critic focal left temporal activity with contralateral irradiation, however without generalization. MRI indicated volumetric asymmetry between hipocampus indicating left mesial temporal sclerosis. Her final diagnosis was temporal mesial lobe epilepsy.

After the patient was designed for epilepsy surgery it was decided to accomplish a Wada test; as, amobarbital is not accessible in our country; propofol was selected as an alternative drug for the test. Before the beginning of the test, it was made 5 minutes of the same tasks of the trial with two objectives: to have a brief evaluation of the normal pattern of memory and speech as well as for the patient get used with the technique. The patient had continuous monitoring of the EEG during the test. After standard cerebral angiography on each side via the right femoral artery to determine whether crossover was present.

The left internal carotid artery was injected first, because it was the side of the proposed surgery. The patient was asked to maintain her arms raised, and 20 miligrams of propofol were then injected into the left internal carotid artery. Eleven seconds afterwards the right arm presented a complete paresis and her speech was blocked for two minutes and for more three minutes the patient indicated mumble in her speech. EEG data showed slow polymorphic activity over the left front-temporal area of the brain. The slowness declined in intensity four minutes later. At the same time the patient returned to baseline motor and speech status.

The memory tasks begun instantaneously after medicine was injected and the test was made using three methods of memory assessment as described in Dodrill ${ }^{8}$. It consists in the Montreal procedure, the Seattle procedure and the Interview procedure. The Seattle procedure ${ }^{9}$ involves naming objects, reading phrases in cards and remembering the object early shown. The Montreal objects were included in the Seattle procedure and after the patient recovered her motor strength and the drug has gone, the Montreal procedure and the Interview procedure come to pass. The patient was under the drug effect for nine minutes and after that the test continued until more five minutes.

Results showed a speech blockage and memory loss. It was decided to repeat the injection on the right side with the purpose of comparison and to observe if the amount of propofol was satisfactory for both injections.

After a 30 minutes delay, the patient had her right hemisphere perfused in the same way as the left. At the second injection the patient had speech blockage for five minutes, then started to answer the test. In the end of six minutes she recovered her arm strength. The effect of the drug in this second injection of propofol lasted 11 minutes, and memory testing was proceeded as in the first injection. The patient described a hot sensation in her head and complained that she wanted but could not speak after the second injection.

\section{DISCUSSION}

The Wada test is part of presurgical evaluation in patients who may underwent an epilepsy surgery, and it is decisive for assuring that after surgery the patient will not develop significant memory or language deficits.

In this patient memory dominance was determined to be in the left hemisphere, and bilateral for speech.

Propofol showed to be good to carry on the Wada test. It was noted that in the second injection the effect of the drug was intense and during more time the patient could not speak. Considering this situation, the testing, that is usually brief, become slower. The time of effect of the drug suggested that the amount has to be lower than the usually used for this procedure. Possibly, the amount of drug given at the second injection could be smaller than in the first, when the second injection is made in the same day.

More tests have to be done to determine the amount of propofol, that more precisely give the similar results than those using amobarbital. 


\section{REFERENCES}

1. Wada J, Rasmussen T. Intracarotid injection of sodium amytal for lateralization of cerebral speech dominance: experimental and clinical observations. J Neurosurg 1960;17:266-282.

2. Milner B, Branch C, Rasmussen T. Study of short-term memory after intracarotid injection of sodium amytal. Trans Am Neurol Assoc 1962;87:224-226.

3. Loring DW, Lee GP, Meador KJ, et al. The intracarotidamorbital procedure as a predicture of memory failure following unilateral temporal lobectomy. Neurology 1960;40:605-610.

4. Wada J. A new method for the determination of the side of cerebral speech dominance: a preliminary report on the intracarotid injection of sodium amytal in man. Igaku to Seibutsugaki 1945;14:221-222.

5. Langley MS, Hell RC. Propofol: a review of its pharmacodynamic and pharmacokinetic properties and use as intravenous anesthetic. Drugs 1988;35:334-372.

6. MacPherson RD. Intraarterial propofol is not directly toxic to vascular endotelium. Anesthesiology 1992;76:967-971

7. Bazin JE, Picard P, Gabrillargues J, Dordain M. Propofol administred via the carotid artery to achieve a Wada test. Can J Anaesth 1998;45:707-708.

8. Dodrill CB, Ojeman GA. An exploratory comparison of three methods of memory assessment with the intracarotid amobarbital procedure. Brain Cognition 1997;33:210-223.

9. Dodrill CB. Preoperative criteria for identifying eloquent brain: intracarotid amytal for language and memory testing. Neurosurg Clin N Am 1993;4:211-215. 